\title{
GAZETTEER OF HYDROLOGIC CHARACTERISTICS OF STREAMS IN MASSACHUSETTS--THAMES RIVER BASIN
}

\author{
By S.William Wandle, Jr., and Janet A. LeBlanc
}

U.S. GEOLOGICAL SURVEY

Water-Resources Investigations Report 84-4287

Prepared in cooperation with the

COMMONWEALTH OF MASSACHUSETTS

DEPARTMENT OF ENVIRONMENTAL QUALITY ENGINEERING

DIVISION OF WATER POLLUTION CONTROL

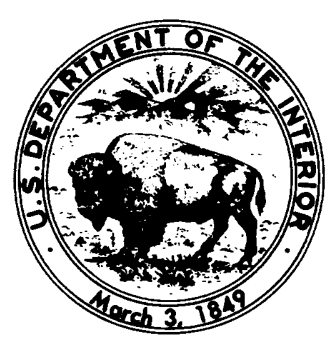

Boston, Massachusetts 1984 
UNITED STATES DEPARTMENT OF THE INTERIOR

WILLIAM P. CLARK, Secretary

GEOLOGICAL SURVEY

Dallas L. Peck, Director

For additional information write to:

U.S. Geological Survey

150 Causeway Street, Suite 1309

Boston, MA 02114
Copies of this report can be purchased from:

Open-File Services Section Western Distribution Branch

U.S. Geological Survey

Box 25425, Federal Center

Denver, CO 80225

Telephone: (303) 236-7476 
Abstract -

Introduction

Hydrologic data

Basin characteristics-

Streamflow characteristics

Streamflow analysis

Streamflow data base -

Daily flow statistics

Low-flow statistics

Summary -

Selected references-_._.

\section{ILLUSTRATIONS}

Figures 1-2. Map showing location of the:

1. Thames River basin

2. gaging stations and low-flow partial-record stations

in the Thames River basin -

3-5. Graphs showing:

3. monthly discharges and extremes for French River at

Webster, Mass. (site 36), during 1961-80

4. flow-duration curve for the Quinebaug River below Westville Dam,

near Southbridge, Mass. (site 16), during 1963-80-1

5. low-flow frequency curve for the French River at

Webster, Mass. (site 36), during 1961-80

Table 1. Stream-order listing, selected drainage areas, and locations

2. Summary of daily flow records and peak-flow records available

in the Thames River basin -

3. Basin characteristics for stream-gaging

stations in the Thames River basin -

4. Streamflow characteristics at selected stream-gaging stations---

5. Summary of 7-day low-flow characteristics, drainage area, and period of record for low-flow partial-record stations 


\section{CONVERSION FACTORS}

The following factors may be used to convert the inch-pound units published herein to the International System of Units (SI).

Multiply inch-pound units

By

To obtain SI Units

\section{Length}

inch (in)

foot $(\mathrm{ft})$

mile (mi)

square mile $\left(\mathrm{mi}^{2}\right)$

cubic foot per second $\left(\mathrm{ft}^{3} / \mathrm{s}\right)$

cubic foot per second per square mile $\left[\left(\mathrm{ft}^{3} / \mathrm{s}\right) / \mathrm{mi}^{2}\right]$

25.4*

0.3048

1.609

Area

2.590

Flow

0.02832

0.01093

Slope

foot per mile ( $\mathrm{ft} / \mathrm{mi})$

0.1894

meter per kilometer $(\mathrm{m} / \mathrm{km})$

\section{Temperature}

Temperature in degrees Fahrenheit $\left({ }^{\circ} \mathrm{F}\right)$ ean be converted to degrees Celsius $\left({ }^{\circ} \mathrm{C}\right)$ as follows:

$$
{ }^{\circ} \mathrm{C}=5 / 9\left({ }^{\circ} \mathrm{F}-32\right) \text {. }
$$

*Exact. 


\title{
GAZETTEER OF HYDROLOGIC CHARACTERISTICS OF STREAMS
}

IN MASSA CHUSETTS--THAMES RIVER BASIN

By S. William Wandle, Jr., and Janet A. LeBlanc

\begin{abstract}
The Thames River basin includes streams draining the Quinebaug River (141 square miles), French River (99.5 square miles), and Middle River (about 6 square miles) basins in south central Massachusetts. Drainage areas, using the latest available 1:24,000 scale topographic maps, were computed for the first time for ungaged streams draining more than 3 square miles and were re-computed for data-collection sites.

Streamflow characteristics at seven gaging stations were calculated using a new data base with daily flow records through 1980. These characteristics include annual and monthly flow statistics, duration of daily flow values, and the annual 7-day mean low flow at the 2-year and 10-year recurrence intervals. Seven-day low-flow statistics are presented for 32 partial-record sites, and procedures used to determine the hydrologic characteristics of a basin are summarized. Basin characteristics representing 14 commonly used indices to estimate various streamflows are provided for seven gaged streams. This gazetteer will aid in the planning and siting of water-resources related activities and will provide a common data base for governmental agencies and the engineering and planning communities.
\end{abstract}

\section{INTRODUCTION}

Information on hydrologic characteristics, including drainage areas, frequency of low flows, and duration of daily flows, is necessary to plan and manage water-resources related activities. Governmental agencies and the engineering and planning community need streamflow and basin characteristics to satisfy requirements relative to waste assimilation, fisheries management, hydropower, land-use planning, stream-systems analysis, and water-resource development and management. No current hydrologic data base containing a comprehensive list 
of drainage areas, monthly flows, low-flow frequencies, and duration of daily flows is available for most of the Massachusetts stream systems. Drainage areas are available for selected sites where streamflow data are collected. Streamflow characteristics are presented in various reports, but these data, to be current, need to be re-analyzed using the latest available daily flow records.

In response to this need, a study was begun in 1980, in cooperation with the Massachusetts Division of Water Pollution Control, to analyze available streamflow and river-basin characteristics, and to compute subbasin drainage areas. This report is part of a series of gazetteers on the hydrologic characteristics of the major river basins in the State. Gazetteers are also available for the coastal river basins of the North Shore and Massachusetts Bay (Wandle, 1984a), Connecticut River basin (Wandle, 1984b), Hudson River basin (Wandle, 1984c), Merrimack River basin (Wandle and Fontaine, 1984), Taunton and Ten Mile River basins (Wandle and Keezer, 1984), Housatonic River basin (Wandle and Lippert, 1984), Blackstone River basin (Wandle and Phipps, 1984), and coastal river basins of the South Shore and Buzzards Bay (Wandle and Morgan, 1984). This report provides the first detailed listing of drainage areas and streamflow characteristics derived from daily flow records in the Thames River basin. A detailed summary of drainage areas for the Connecticut part of the Thames River basin is given in Thomas (1972). The daily streamflow characteristics presented are an expansion and an update of those given in (V. A. Eames, U.S. Geological Survey, written commun., 1984).

The Thames River basin in Massachusetts (fig. 1) includes the Quinebaug, French, and Middle River basins in south-central Massachusetts. The study area includes all or part of the following communities: Auburn, Brimfield, Brookfield, Charlton, Douglas, Dudley, East Brookfield, Holland, Leicester, Millbury, Monson, Oxford, Southbridge, Spencer, and Sturbridge, Sutton, Wales, Warren, Webster, and West Brookfield.

Streamflow characteristics presented for seven continuously gaged streams are based upon a new sample of daily flow records in comparison to flow records used by V. A. Eames (U.S. Geological Survey, written commun., 1984), Higgins (1967), Knox and Soule (1949), and Male and Ogawa (1982). Streamflow records through the 1980 water year were available for this analysis. Records were selected for each site to represent a flow regime influenced by fairly constant river basin conditions (Wandle, 1983).

Drainage areas were computed for the first time for ungaged streams draining more than $3 \mathrm{mi}^{2}$ and were re-computed for data-collection sites. Drainage divides, as delineated on the latest available 1:24,000 scale topographic quadrangle maps (Brackley and Wandle, 1982; Krejmas, 1982; Krejmas and Wandle, 1982) were used to calculate drainage areas. Drainage areas for most of the long-term gaging stations in earlier reports were computed using the drainage divides as outlined on $1: 31,680$ or $1: 62,500$ scale topographic quadrangle maps.

Streamflow data used in this study are a part of the historic streamflow data collected under agreements with State and Federal agencies and the U.S. Geological Survey. Most of the low-flow discharge measurements used in determining low-flow estimates at partial-record sites were collected during the water-resources investigation of the French-Quinebaug River basin (V. A. Eames, U.S. Geological Survey, written commun., 1984) and during the 1960's as part of the Massachusetts low-flow network. The file of basin characteristics was created during an evaluation of available streamflow data in central New England (Johnson, 1970). This file is an expansion of the characteristics abstracted by Langbein and others (1947), and by Benson (1962). Basin characteristics were updated and additional characteristics were entered as part of a study to define floodflow characteristics of small streams (Johnson and Tasker, 1974; Wandle, 1982). The hierarchical stream list was compiled by the Massachusetts Division of Water Pollution Control and the Massachusetts Division of Fisheries and Wildlife (Halliwell and others, 1982).

Data tabulated include drainage areas, basin and streamflow characteristics for gaging stations, including annual and monthly flow statistics, duration of daily flow values, and the annual 7-day mean low flow at the 2-year and 10-year recurrence intervals. Seven-day lowflow statistics for partial-record sites are also presented. An explanation of each procedure to determine the streamflow and basin characteristics is provided.

The authors thank the many persons who have kindly given time, information, and guidance during this study. Particular thanks are given to persons in the Geological Survey who assisted in the data collection and in the preparation of this report. 


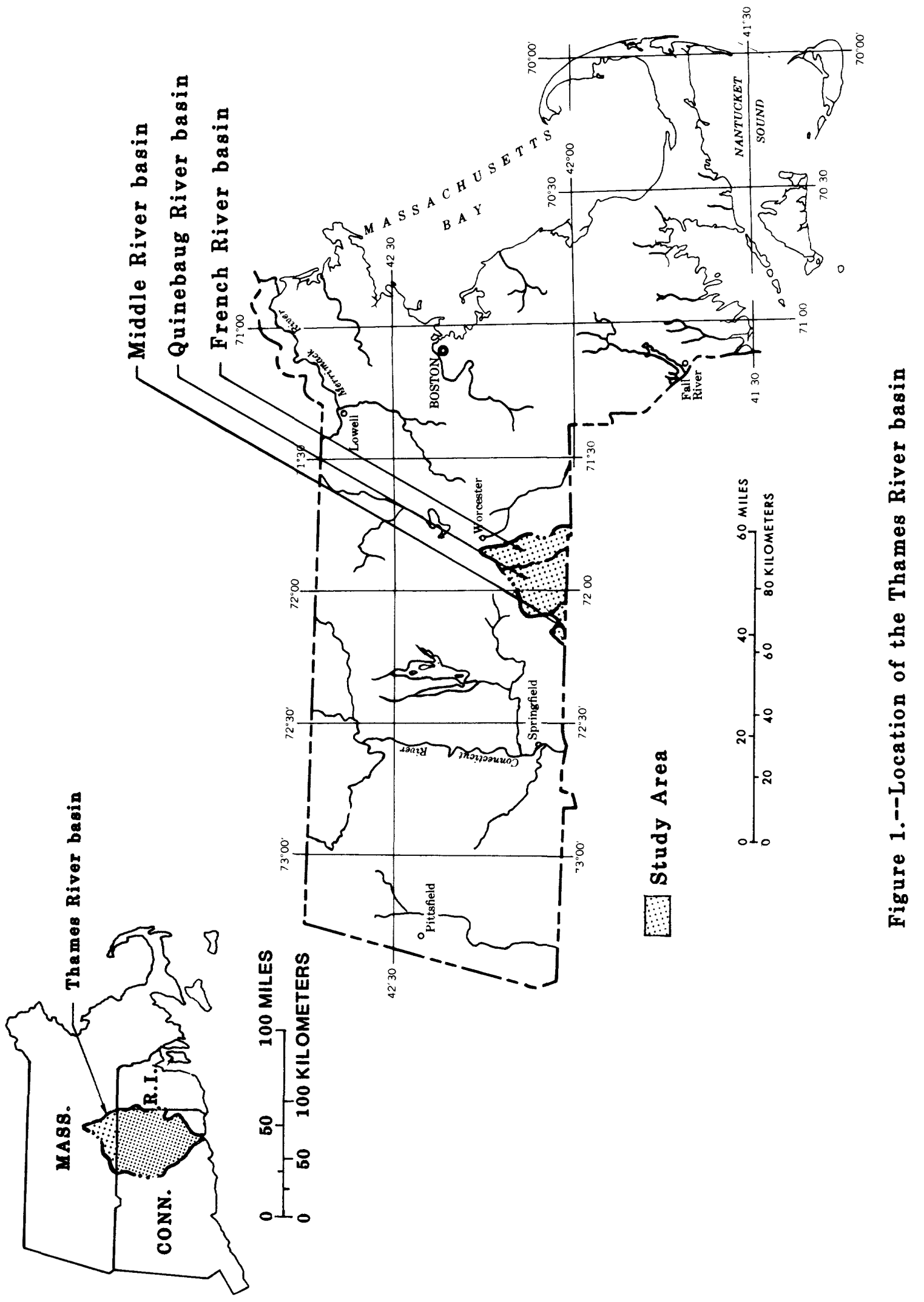




\section{HYDROLOGIC DATA}

Hydrologic characteristics are represented by various physical, climatic, and streamflow indices of a river basin. These characteristics can be determined either from available maps by following standardized procedures or from historic streamflow records.

Basin characteristics are indices of the physiography of the basin or of the climate prevailing over the basin and are measured on topographic quadrangle or climatic maps. Streamflow characteristics are computed from continuous records of daily flow or from a set of measurements during the occurrence of a specific event. Streamflow and basin characteristics are used in modeling stream quality, assessing water-resources conditions, analyzing impact of man's activities, and defining relationships to estimate flows or stream-quality parameters at ungaged sites.

\section{Basin Characteristics}

Drainage area is one of the most important variables in any hydrologic investigation or in the design of riverine structures because it is the most significant variable in the northeast that influences all streamflow, except perhaps low flow in some regions. The physical boundary for many water-related studies corresponds to the limits for the drainage area upstream from the site.

For this study, drainage areas listed in table 1 (at the end of the report) were determined for the following sites:

1. Survey data-collection sites shown in figure 2. These sites include continuous-record gaging stations given in table 2 (at the end of the report), low-flow partial-record stations, miscellaneous sites, and water-quality stations.

2. Locations where the drainage area is greater than $3 \mathrm{mi}^{2}$.

3. Successive sites along a stream where the area between sites is at least $6 \mathrm{mi}^{2}$ on tributary streams and $10 \mathrm{mi}^{2}$ on the French or Quinebaug River.

The drainage basin divides for these sites were delineated on the latest available 1:24,000 scale topographic quadrangle maps. Subbasin drainage divides are shown in the series of statewide reports, "Drainage Divides, Massachusetts." The Thames River basin is covered by three reports-Blackstone and Thames River basin (Krejmas, 1982), Connecticut River Lowlands and Chicopee River basin (Krejmas and Wandle, 1982), and Nashua and Concord River basins (Brackley and Wandle, 1982).

The subbasin drainage areas given in table 1 are indexed to the Massachusetts stream inventory prepared by the Massachusetts Division of Water Pollution Control and the Massachusetts Division of Fisheries and Wildlife (Halliwell and others, 1982) with some modification. Drainage areas were computed for sites meeting one of the three criteria mentioned above. The entire stream listing is included as a reference for stream order. This hierarchical listing begins at the mouth of a major stream and proceeds upstream with tributary streams indented under the main-stem stream. This order is followed to list all named streams. Unnamed tributaries are included to maintain the hierarchy. The reader is referred to the inventory of rivers and streams report by Halliwell and others (1982) for a more detailed explanation.

The basin characteristics listed below are included because they represent indices that would remain reasonably stable over a planning period. They are useful in predictive surfacewater models to assess impacts of proposed developments. The usefulness of these characteristics to explain the variability of various streamflow events has been demonstrated in hydrologic analyses (Thomas and Benson, 1970) and they can be measured readily from available maps. The 14 basin indices given in table 3 (at the end of the report) were computed according to the procedures described below. The indices for elevation, storage, lake area, and forest can be computed by the grid method which is explained after all the procedures are described. 


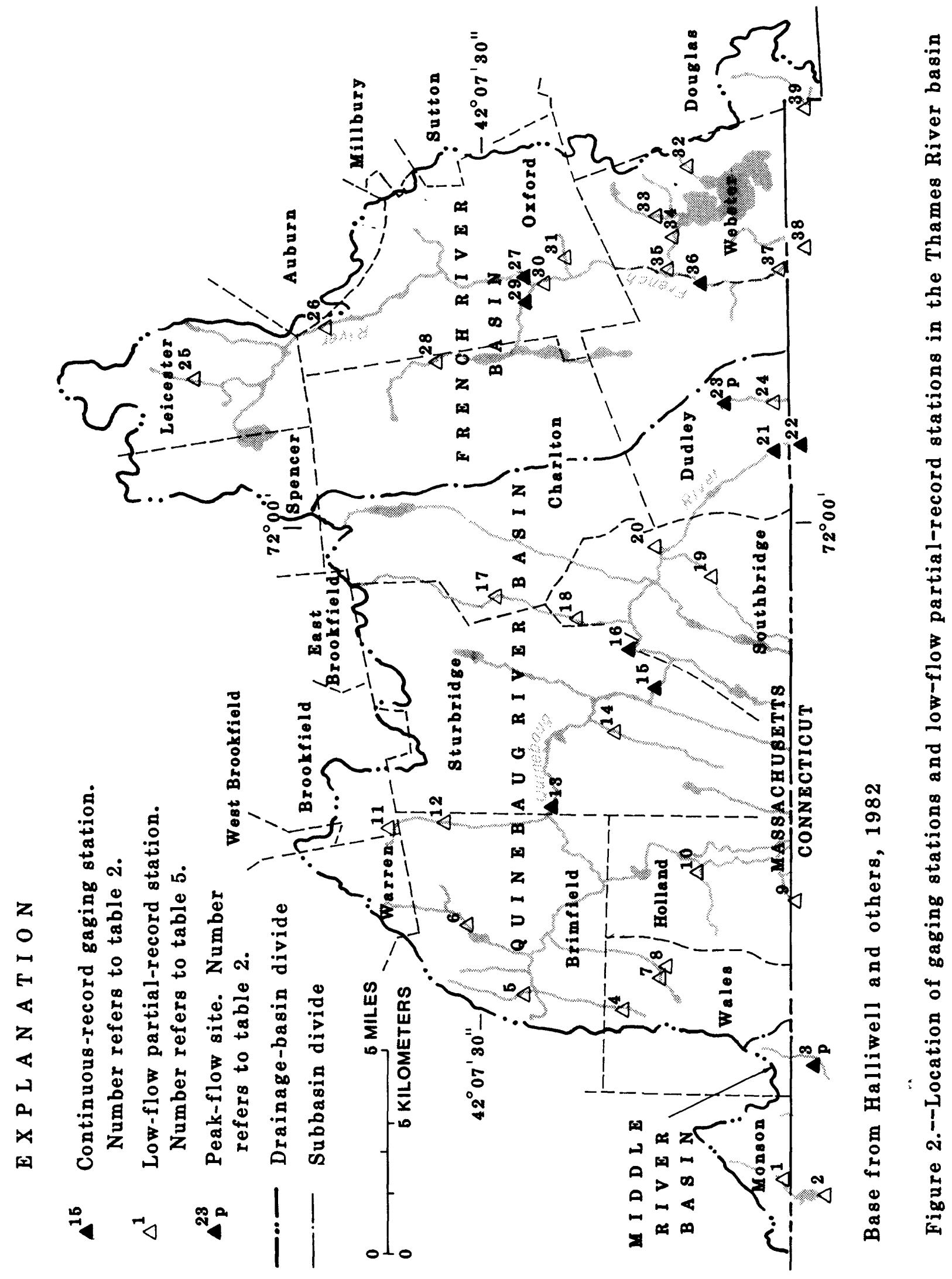


1. Drainage area-Area, in square miles, as measured on the most recent 1:24,000 scale topographic quadrangle maps. Drainage area, as defined in the "National Handbook of Recommended Methods for Water-Data Acquisition" (U.S. Geological Survey, 1977), is "...the area of a river basin, measured in a horizontal plane, that is enclosed by a topographic divide such that direct surface runoff from precipitation normally would drain by gravity into the river basin.". Drainage area boundary lines are traced on topographic maps along divides indicated by contour elevations, starting at the point on the stream for which the drainage area is desired. These lines are drawn to cross a contour at right angles. Interpolation between contours may be indicated by reference to trails, old roads, or firebreaks in forested areas, all of which frequently follow drainage divides. Detailed information may also be obtained from highway or street profiles, from examination of aerial photographs, and from ground reconnaissance. Subareas within each quadrangle map were computed with an electronic digitizer using the procedures of the U.S. Federal Inter-Agency River Basin Committee (1951) as a guide. The coefficients to compute square miles from digitizer units were calculated using the known area of each 7.5-minute quadrangle or of the appropriate 2.5-minute quadrilaterals. Drainage areas for the subbasins were computed by summing the contributing areas.

2. Slope--Main-channel slope, in feet per mile, determined from elevations at points 10 percent and 85 percent of the distance along the main channel from the gaging station to the basin divide.

3. Length--Main-channel length, in miles, from the gaging station to the basin divide, as measured with dividers set to 0.1 mile or with a map measurer.

4. Elevation--Mean basin elevation, in feet above sea level, measured on topographic maps by laying a grid over the map.

5. Storage--Area of lakes, ponds, and marshes, in percent of total drainage area, measured by planimetering or by using a transparent grid. The marsh area includes the area of wooded marshes and marshes as defined by the appropriate topographic quadrangle map symbol. Storage area is the total area of all the lakes, ponds, and marshes expressed as a percentage of the total drainage area.

6. Lake area--Area of lakes and ponds, in percent of the drainage area, determined by the grid method.

7. Forest-Area of forest, in percentage of the drainage area, determined from the forest cover as shown on the topographic map with the green woodland overprint using the grid method.

8. Soil--Soil index, in inches, represents the value of potential maximum infiltration, during an annual flood, under average soil-moisture conditions. This characteristic, provided by the U.S. Soil Conservation Service (Dr. Benjamin Isgur, written commun., 1970), is a function of the soil and cover conditions in the basin. The index was computed from the runoff curve number following procedures in U.S. Department of Agriculture (1972).

9. Latitude-Latitude of stream-gaging station, in decimal degrees, determined by manual measurement.

10. Longitude--Longitude of stream-gaging station, in decimal degrees, determined by manual measurement.

11. Precipitation--Mean-annual precipitation, in inches, determined from the isohyetal map in Knox and Nordenson (1955). The variation in mean-annual precipitation is shown in more detail in this map than in more recent sources.

12. Precipitation intensity--Maximum 24-hour rainfall, in inches, having a recurrence interval of 2 years. This characteristic was determined from U.S. Weather Bureau (1959b).

13. Snowfall--Average total seasonal snowfall, in inches, from an isohyetal map in Lautzenheiser (1969).

14. January temperature-Minimum January temperature, in degrees Fahrenheit, determined from U.S. Weather Bureau (1959a). 
Several basin characteristics were measured following the grid method by using transparent grids to compute area or an average contour value. Storage area is determined by randomly placing the grid over the water and marsh area and counting squares. If the water and marsh area is large enough (about 30 squares), the number of grid intersections within the storage area are counted. The storage area then is computed as the product of the square size and the number of grid intersections. To measure a contour value such as elevation, the grid spacing is selected to give at least 25 intersections within the basin boundary. The elevation at each grid intersection is determined and an average is computed. The percentage of a variable that is extensive in a drainage basin, such as forest cover, can be easily measured by counting the number of grid intersections occurring over the forested area, multiplying by 100 , and dividing by the number of grid intersections within the basin.

\section{Streamflow Characteristics}

Historic daily flow records available in the Quinebaug and French River basins were used to compute daily, monthly, and annual flow characteristics. A summary of these records is given in table 2 and the location of streamflow sites is shown in figure 2. These flow data were collected as part of the Survey's nationwide data-collection network through agreements with State and Federal agencies. Records of daily flow are available from the Survey's National Water Data Storage and Retrieval System (WATSTORE). This water-data computer processing system consists of several files containing data grouped by common characteristic and datacollection frequency.

The WATSTORE system includes site identification, daily values files, and computer programs that produce streamflow statistics. Hydrologic-data files are maintained for (1) parameters measured on a daily or continuous basis, such as streamflow values, river stages, water temperatures, specific-conductance values, and ground-water levels; (2) annual peak values for streamflow and stage; (3) chemical analyses for surface- and ground-water sites; and (4) groundwater site inventory, including location, identification and geohydrologic characteristics. The data-processing, storage, retrieval, and analysis capabilities of WATSTORE are described in the system user's guide compiled by Hutchison (1975). Information on the availability of data analyses may be obtained from: U.S. Geological Survey, 150 Causeway Street, Suite 1309, Boston, MA 02114.

A brief description of the streamflow statistics computed using the WATSTORE system is included below. Streamflow characteristics representing annual, monthly, and daily flow statistics were selected for this analysis because they are useful in planning and design studies in this region. The streamflow statistics computed following the procedures given below are listed in table 4 (at the end of the report).

Annual and monthly flow characteristics (means and standard deviations) for seven gaging stations were computed with the "Daily Values Monthly and Annual Statistics" computer program W4422 (Price and Meeks, 1977) using observed daily flow records. The maximum and minimum, monthly means (fig. 3 and table 4) were obtained from output provided by this program. The monthly hydrograph for French River at Webster is shown in figure 3.

Characteristics of the flow-duration curve (the daily flow exceeded 99, 95, 90, 75, 70, 50, 25, and 10 percent of the time) were computed for seven gaging stations by means of computer program A969, "Daily Values Statistics" (Meeks, 1977). An example of a flow-duration curve for Quinebaug River below Westville Dam, near Southbridge is given in figure 4. Low-flow characteristics (annual 7-day mean low flows at the 2-year and 10-year recurrence intervals 7Q2 and 7Q10, respectively) were also calculated for three gaging stations by program A969. In this program, a log-Pearson Type III distribution is fitted to a set of observed annual 7-day mean low flows to obtain coordinates of the computed low-flow frequency curve. If the log-Pearson Type III curve did not adequately fit a plot of the observed data, especially in the low end, then a graphical curve was drawn. The graphical frequency curve was used to interpret the observed data when necessary because a graphical curve is the basic curve to use in analyzing the frequency of annual low flows according to Riggs $(1971,1972)$. The frequency curve for French River at Webster is shown in figure 5.

Additional flow data, including flood-frequency analyses, are available from WATSTORE. Peak discharges for selected recurrence intervals for 82 sites in Massachusetts are given in Wandle (1982). 


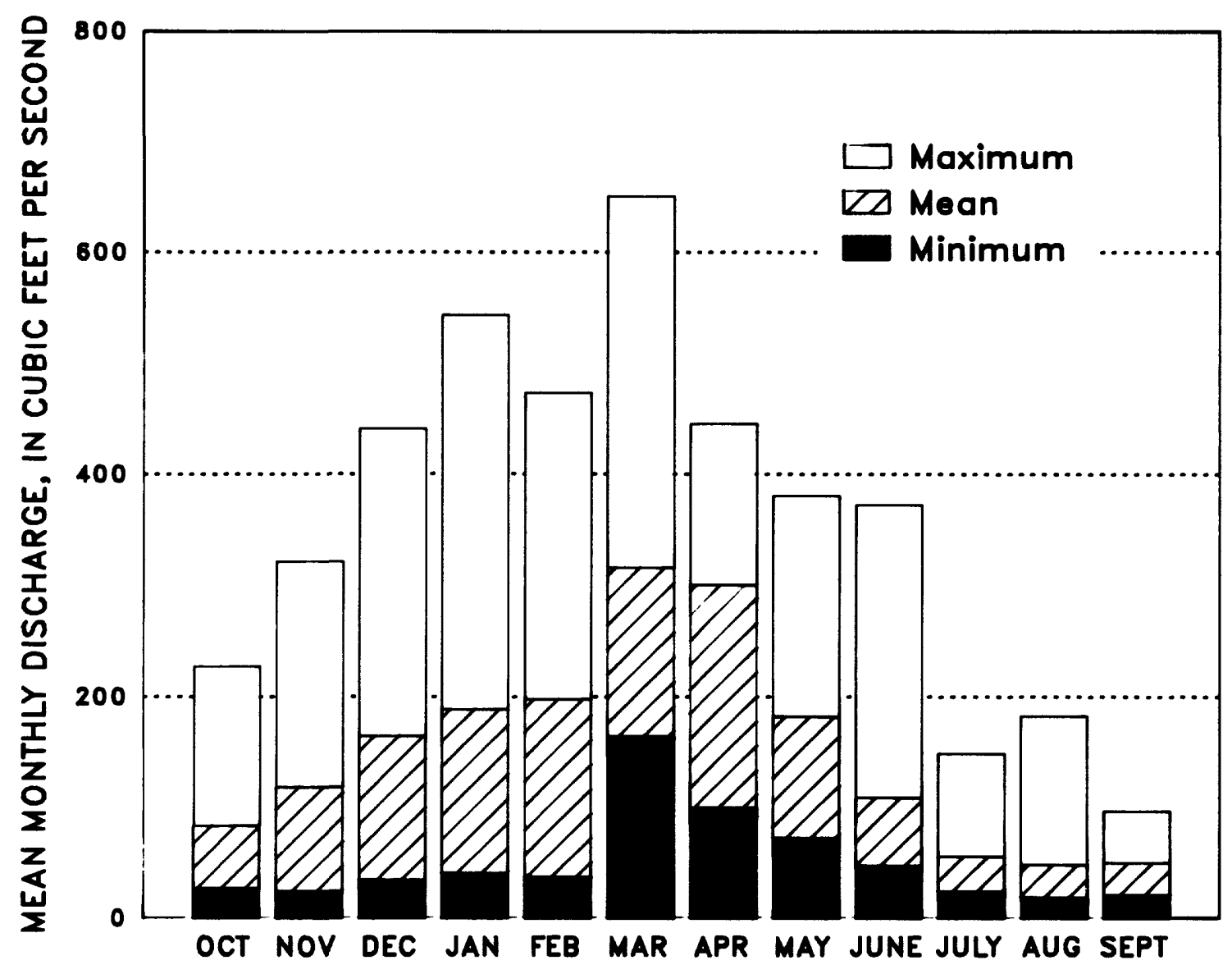

Figure 3.--Monthly discharges and extremes for the French River at Webster, Mass. (site 36), during 1961-80 


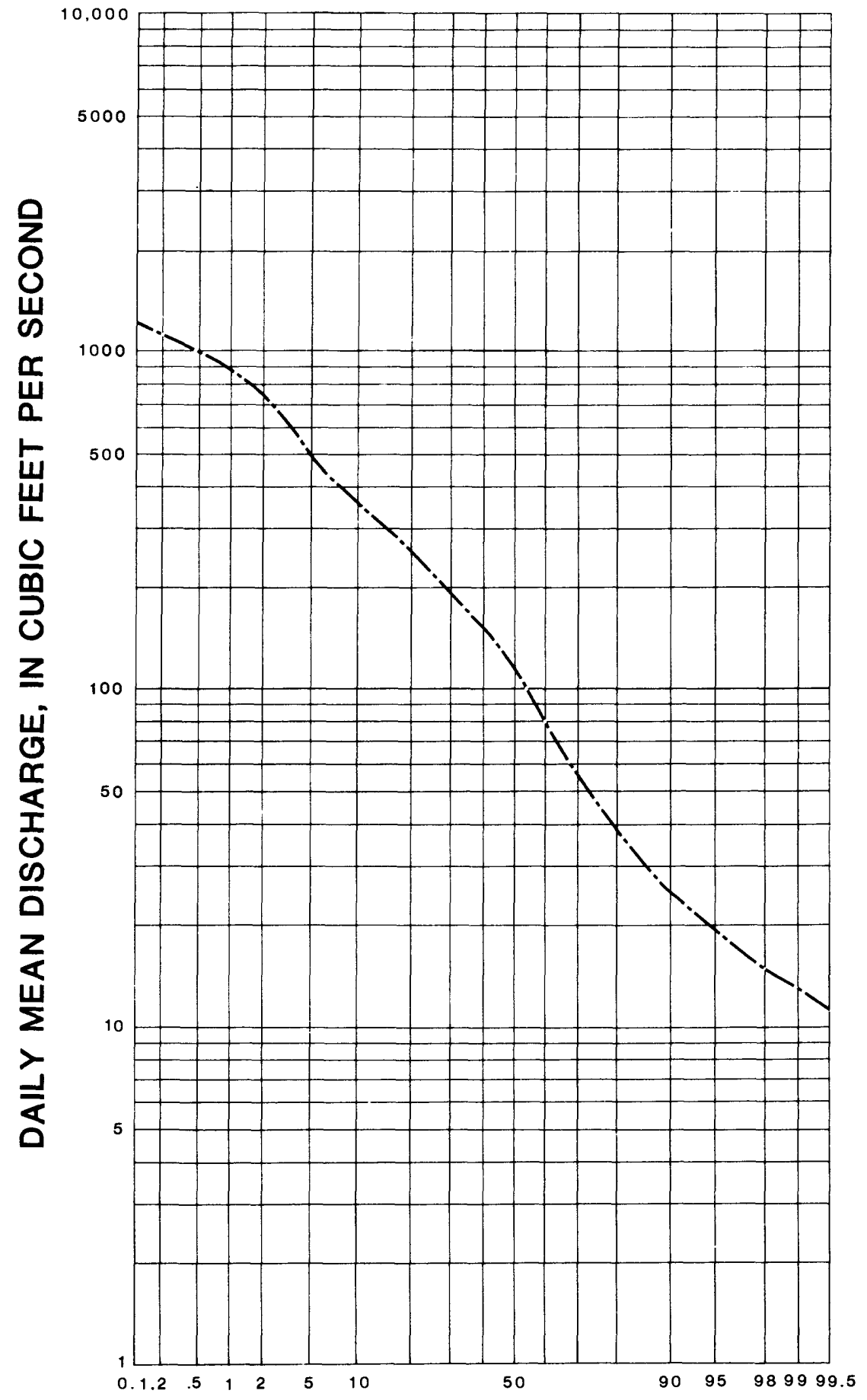

\section{PERCENTAGE OF TIME INDICATED DISCHARGE WAS EQUALED OR EXCEEDED}

Figure 4.--Flow-duration curve for the Quinebaug River below Westrille Dam, near Southbridge, Mass. (site 16), during 1963-80 


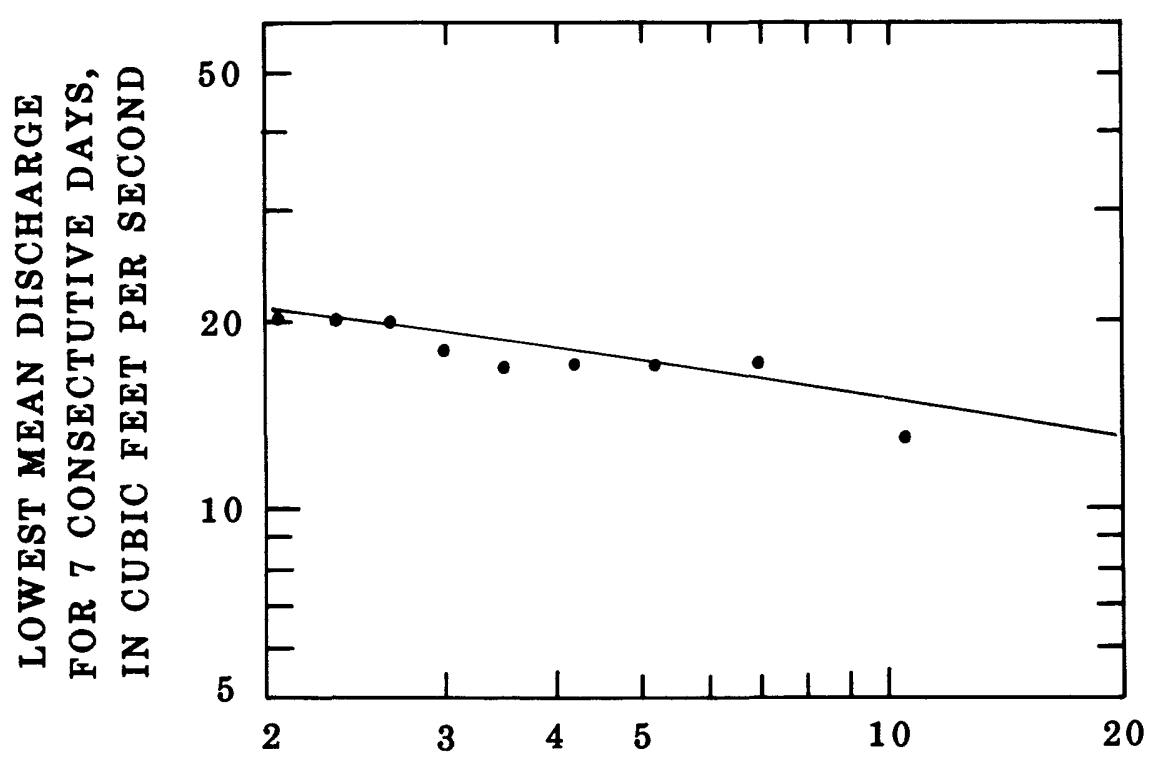

RECURRENCE INTERVAL, IN YEARS

Figure 5.--Low-flow frequency curve for the French River at Webster, Mass. (site 36), during 1961-80

Characteristics of low flow were also determined at low-flow partial-record stations where measurements of discharge, rather than a continuous daily flow record, were available. This estimating technique is briefly described in the section on Streamflow Analysis. The 7-day low-flow statistics were developed from discharge measurements made during periods of base runoff. Base runoff is defined (Langbein and Iseri, 1960) as "the sustained or fair weather runoff. In most streams, base runoff is composed largely of ground-water effluent." Base runoff usually occurs in most Massachusetts streams during the summer or early fall after 5 to 7 consecutive days without rainfall.

\section{STREAMFLOW ANALYSIS}

\section{Streamflow Data Base}

Systematic records of daily streamflow have been collected since 1932 in the Quinebaug River basin and since 1940 in the French River basin. The location and period of record for these gaging stations are given in table 4. Streams within the Middle River basin are not monitored in Massachusetts. Streamflow records for the Thames River basin in Connecticut, are available from the Survey office in Hartford, Connecticut.

Discharge measurements were made at 20 low-flow partial-record sites during the waterresources investigation of the French and Quinebaug River basins (V. A. Eames, U.S. Geological Survey, written commun., 1984). Measurements were also collected as part of the Massachusetts low-flow network at 10 sites during 1960-62 and 1965-66 and at three sites during 197982. Data are available as part of the Connecticut water-resources program in the Middle River and Quinebaug River basin, just south of the state line. Discharge measurements were made for Middle River at Ellithorpe, Delphi Brook near Staffordville, English Neighborhood Brook at North Woodstock, and Muddy Brook at East Woodstock, all of which are in Connecticut.

Flow characteristics are useful in resource management and design studies if these variables represent a particular regulated flow sequence or the natural flow regime that is expected to occur in the future. A valid streamflow analysis is based upon flow records during a period of relatively constant river-basin conditions. 


\section{Daily Flow Statisties}

Systematic daily flow records from eight sites in the French and Quinebaug River basins were reviewed to select a data base for statistical analysis. Impacts of reservoirs, diversions, regulation, and withdrawals for public supplies were assessed using information on stream regulation found in the series of water-resources data reports issued annually (see U.S. Geological Survey, 1980, for an example) and in Knox and Soule (1949). Streamflow records for seven sites were selected that represent a flow regime influenced by fairly constant river-basin conditions (Wandle, 1983). The record length used in this analysis is given in table 4. Low flow, monthly flow, and flow-duration characteristics given in table 4 were derived from the observed streamflow records at each station and were not adjusted for regulation or diversion. These daily streamflow characteristics were computed following procedures summarized in the section on streamflow characteristics.

Statistics are not included for the Quinebaug River at Westville. These data represent the streamflow prior to the completion of Westville Lake in 1962 and they are not indicative of current conditions.

\section{Low-Flow Statistics}

Continuous streamflow records are not necessary to estimate low-flow characteristies at sites. According to Riggs (1972), selected base-flow measurements rather than a continuous daily flow record can define the low-flow characteristics at a site.

Low-flow partial-record stations are operated to collect discharge measurements when streamflow is composed largely of ground-water runoff. These low-flow sites are selected on streams where flow is expected to occur during a significant dry spell and where the flow is not affected by artificial regulation. Base-flow measurements to define a relation with concurrent gaged flows are obtained over several low-flow periods.

A relation is developed with the base-flow measurements and the concurrent daily mean flows at a nearby long-record gaging station (index station). The 7-day low-flow statistics (7Q2 and $7 Q 10)$ for the site are determined from this relation using the appropriate low-flow statistics for the gaged stream. This estimating technique is explained in more detail by Riggs (1972).

The 7-day 10 year low-flows for the four sites in Connecticut were computed from a regression equation developed by Cervione and others, 1982. This estimating equation is $7 Q 10=0.67 \mathrm{~A}_{\mathrm{sd}}+0.01 \mathrm{~A}_{\text {till }}$, where $\mathrm{A}_{\mathrm{sd}}$ is the drainage area, in square miles, underlain by coarse-grained stratified drift; and $A_{t i l l}$ is the drainage area, in square miles, underlain by till-mantled bedrock.

Low-flow statistics for 32 sites in the Thames River basin are summarized in table 5 (at the end of the report). The low-flow statistics are representative of the hydrologic regime during the data-collection period. Seven-day, 2-year, and 10-year low flows ranged from 0 to 0.38 and from 0 to $0.25\left(\mathrm{ft}^{3} / \mathrm{s}\right) / \mathrm{mi}^{2}$, respectively, at these sites. Quaboag River at West Brimfield, Mass., Quinebaug River at Quinebaug, Conn., and Little River near Hanover, Conn., were used as the index stations. These values were computed following the procedures mentioned above.

\section{SUMMARY}

Drainage areas were re-computed for data-collection sites and were computed for the first time for ungaged streams draining greater than $3 \mathrm{mi}^{2}$. Basin characteristics for drainage area, slope, length, elevation, storage, lake area, forest, soil, latitude, longitude, precipitation, precipitation intensity, snowfall, and January minimum temperature are provided for the seven gaged sites in the Thames River basin. Computer programs A969 and W4422 were used to determine daily flow statistics including annual and monthly flows, duration of daily flows, and 7-day low-flow values. Seven-day, 2-year, and 10-year low flows ranged from 0 to 0.38 and from 0 to $0.25\left(\mathrm{ft}^{3} / \mathrm{s}\right) / \mathrm{mi}^{2}$, respectively, at the 32 partial-record stations.

Techniques used to compute basin and streamflow characteristics of a river basin are summarized. This gazetteer contains a comprehensive listing of hydrologic characteristics that should prove useful to those concerned with water-resources activities. 
Table 1.-Stream-order listing, selected drainage areas, and locations of subbasins within the Thames River basin

[Sites with streamflow information listed in tables 2, 4, or 5 are marked with an asterisk. The hierarchical listing is modified from Halliwell and others, 1982. Drainage areas are shown for sites as explained in the section on basin characteristics. These areas are not adjusted for manmade changes in the flow system. Streams entirely in adjacent states are underlined and are included in the list where necessary to maintain the stream order.]

Thames River (Conn.)-continuation of Shetucket River Shetucket River (Conn.)-continuation of Willimantic River

QUINEBAUG RIVER BASIN

Quinebaug River

Fivemile River (Conn.)

Rocky Brook

East Thompson Road

$* 4.97$

FRENCH RIVER BASIN

French River

Long Branch Brook

Freemans Brook

French River

Potash Brook

Unnamed tributary

French River

Mill Brook

Mill Brook

Unnamed tributary

Sucker Brook

Mine Brook

Sucker Brook

Browns Brook

Browns Brook

French River tributary

Unnamed tributary

Unnamed tributary

Unnamed tributary

French River

Little River

Little River

Little River

South Fork

Unnamed tributary

Little River
Labby Road

$* 3.19$

Perryville Road

$* 93.2$

Low Pond outlet 100 feet downstream from Mill Street

50 feet upstream from Pleasant Road

Bigelow Road

Lake Chaubunagungamaug outlet

100 feet downstream from Club Pond

Mine Brook Road

Mouth

Nipmuc Pond outlet

Mouth

State Route 16

Nelson Street

Lowes Pond outlet

Slaters Pond outlet

Robinson Pond outlet

Dudley Road

0.6 mile upstream from mouth

Buffum Pond outlet

Buffumville Lake outlet

Granite Reservoir outlet

50 feet downstream from Gore Pond outlet

400 feet downstream from Turner Road
$* 84.0$

$* 10.7$

*10.3

4.15

*2.54

1.03

1.06

1.22

$* .49$

$* 8.56$

7.83

2.33

1.14

*58.1

*26.0

25.3

24.5

7.80

2.10

10.5 
Table 1.--Stream-order listing, selected drainage areas, and locations of subbasins within the Thames River basin (Continued)

Stream name Location

Drainage area, in square miles

\section{FRENCH RIVER BASIN (Continued)}

Shetucket River (Conn.) (Continued)

Quinebaug River (Continued)

French River (Continued

Little River

French River

French River

Wellington Brook

French River

French River

French River

Grindstone Brook

Town Meadow Brook

Burncoat Brook Unnamed tributary Unnamed tributary

Bartons Brook

Unnamed tributary

Unnamed tributary
U.S. Route 20

240 feet downstream from Hodges Village Dam Hodges Village Dam outlet

Pond outlet, 1.2 miles upstream from MeIntyre Road

U.S. Route 20

Cominsville Road

*20.0

Cedar Meadow Pond outlet

Sargent Pond outlet

2.78

Greenville Pond outlet

8.24

Stiles Reservoir outlet

4.64

Inlet to Stiles Reservoir

0.15 mile upstream from mouth

$* 2.40$

\section{QUINEBAUG RIVER BASIN}

Quinebaug River

Tufts Branch

Tufts Branch

Tufts Branch

Quinebaug River

Quinebaug River

Lebanon Brook

Lebanon Brook

Lebanon Brook

Quinebaug River trib. no. 2

Unnamed tributary

Unnamed tributary Cohasse Brook

Cady Brook

Cady Brook Unnamed tributary Unnamed tributary

Pratt Brook

Me Kinstry Brook

Me Kinstry Brook

Me Kinstry Brook
Mouth

State Route 197

$* 2.40$

Dudley Southbridge Road

500 feet upstream from State Route 197

*1.10

State Route 131

$* 156$

Dam 0.15 mile upstream from mouth

*156

State Route 169

10.2

*9.66

Upper unnamed pond outlet

7.12

Road to treatment plant

*9.40

Mouth

4.18

Wells Pond outlet

3.15

Cohasse Brook Reservoir inlet

1.75

Mouth

11.6

1.2 miles upstream from mouth

11.3

Sibley Ponds(lower) outlet

2.95

Sibley Ponds(upper) 100 feet

downstream from outlet

Mouth

8.04

Plimpton Street

*7.69

Hill Road 
Table 1.--Stream-order listing, selected drainage areas, and locations of subbasins within the Thames River basin (Continued)

Stream name Location

Drainage

area,

in square

miles

\section{QUINEBAUG RIVER BASIN (Continued)}

Shetucket River (Conn.) (Continued)

Quinebaug River

Quinebaug River

Hatchet Brook

Quinebaug River

Breakneck Brook

Breakneck Brook

Unnamed tributary

Hobbs Brook

Hobbs Brook

Hamant Brook

Unnamed tributary

Quinebaug River

Quinebaug River

Quinebaug River

Quinebaug River tributary

Unnamed tributary

Quinebaug River tributary

Quinebaug River tributary

Mill Brook

Wales Brook

Wales Brook tributary

Wales Brook

Wales Brook

Wales Brook

Wales Brook

Unnamed tributary

East Brook

Sessions Brook

West Brook

Mountain Brook

Charles Brook

Hollow Brook

Hollow Brook

Quinebaug River

Quinebaug River

Stevens Brook

Browns Brook

Browns Brook

May Brook

Leadmine Brook

Leadmine Brook

Wells Brook (Conn.)
200 feet downstream from Westville Dam

Westville Reservoir outlet

$* 99.0$

Mouth

0.45 mile downstream from Breakneck Brook

Mouth

Breakneck Pond outlet

99.0

3.94

$* 93.6$

4.39

1.67

Mouth

Mouth

.89

7.26

3.82

*3.37

3.44

71.2

Leadmine Road

750 feet downstream from

East Brimfield Dam

East Brimfield Lake outlet

*67.4

67.4

Alum Pond outlet

.95

Sturbridge Road

$* 5.32$

Brookfield Road

*2.09

Mouth

14.2

Mouth

6.57

*.73

$\begin{array}{lr}0.3 \text { mile downstream from Holland Road } & 3.83 \\ \text { Holland Road } & * 3.64\end{array}$

Laurel Hill Road

2.21

1.50

4.20

Mouth

Bridge 400 feet upstream from

Sherm an Pond

*2.30

Mouth

1.90

1.41

$* 1.40$

U.S. Route 20

.94

3.26

$* .80$

Hollow Road

East Brimfield Road

25.2

Hamilton Reservoir outlet

22.8

$* 4.40$

Mashapaug Road

3.02

1.86

*3.02

3.06

.88

*2.06a 
Table 1.--Stream-order listing, selected drainage areas, and locations of subbasins within the Thames River basin (Continued)

\section{QUINEBAUG RIVER BASIN (Continued)}

Willimantic River (Conn.)-continuation of Middle River

MIDDLE RIVER BASIN

Middle River (Conn.)

Crow Hill Brook

Middle River (Conn.)

Sawmill Brook

State Route 32

$*^{1} 6.46$

Sawmill Brook

State Line Pond inlet

Stafford Hollow Road

Alden Brook

Potash Brook

Delphi Brook

Mouth

Delphi Brook

State Route 19

1 From Thom as, 1972.

a Drainage basin is outside of Massachusetts. 
Table 2.--Summary of daily flow records and peak-flow records available in the Thames River basin

Number

in fig- Station

Station name

Period

ure 2 number

Location

of

record

Remarks

301119255 Delphi Brook near Staffordville, Conn.

801123160 Wales Brook tributary near Wales, Mass.

1301123360 Quinebaug River below Brimfield Dam, at Fiskdale, Mass.

1501123500 Quinebaug River at Westville, Mass.

1601123600 Quinebaug River below Westville Dam, near Southbridge, Mass.

2101123990 Quinebaug River near Dudley, Mass.

2201124000 Quinebaug River at Quinebaug, Conn.

$\begin{array}{ccc}23 & 01124050 & \begin{array}{l}\text { Tufts Branch at } \\ \text { Dudley, Mass. }\end{array} \\ 27 & 01124350 & \begin{array}{l}\text { French River below } \\ \text { Hodges Village Dam, at } \\ \text { Hodges Village, Mass. }\end{array}\end{array}$

$29 \quad 01124500 \quad$ Little River near Oxford, Mass.

3201124750 Browns Brook near Webster, Mass.

$36 \quad 01125000 \quad$ French River at Webster, Mass.
State Route 19

Holland Road

750 feet upstream from East Brimfield

0.45 mile downstream from Breakneck Brook

200 feet downstream from Westville Dam

State Route 131

500 feet upstream from State Route 197

Dudley Southbridge Road

240 feet downstream from Hodges Village

0.6 mile upstream from mouth

State Route 16

50 feet upstream from Pleasant Street
1964-76 Peak-flow site discontinued.

1964-80 Peak-flow site.

1973-80 Regulated by East Brimfield Lake.

1940-62 Regulated by mills and by East Brimfield Lake since 1960. Backwater from Westville Lake since 1962.

1963-80 Regulated by East Brimfield and Westville Lakes and other reservoirs.

1969-80 Water-quality monitor.

1932-80 Regulated by East Brimfield Lake since 1960 and by Westville Lake since 1962.

1963-80 Peak-flow site.

1963-80 Regulated by Hodges River Reservoir.

1940-80 Regulated by Buffumville Lake since 1958 , by other reservoirs, and by mill prior to 1958.

1963-77 Discontinued.

1950-80 Regulated by mills, by Lake Chaubunagungamaug, by Buffumville Lake since 1958 , by Hodges Village Reservoir since 1960, and by smaller reservoirs. 
Table 3.--Basin characteristics for stream-gaging stations in the Thames River basin

Basin characteristics
Station name and site number

\begin{tabular}{|c|c|c|c|c|c|}
\hline Delphi & Wales & Quinebaug & Quinebaug & Quinebaug & \\
\hline $\mathrm{Br}$ & Brook & River below & River & River below & Quinebaug \\
\hline & tributary & East Brim- & at & Westville & Rive \\
\hline $\begin{array}{l}\text { Sta ffords- } \\
\text { ville, } \\
\text { Conn. }\end{array}$ & $\begin{array}{l}\text { near } \\
\text { Wales, } \\
\text { Mass. }\end{array}$ & $\begin{array}{l}\text { field Dam, } \\
\text { at Fiskdale, } \\
\text { Mass. }\end{array}$ & $\begin{array}{l}\text { West- } \\
\text { ville, } \\
\text { Mass. }\end{array}$ & $\begin{array}{c}\text { Dam, near } \\
\text { Southbridge, } \\
\text { Mass. }\end{array}$ & $\begin{array}{l}\text { Quine- } \\
\text { baug, } \\
\text { Conn. }\end{array}$ \\
\hline
\end{tabular}

(8)
(13)
(15)
(16)
(22)
Area, in square m
Slope, in feet per
mile

Length, in miles

Elevation, in feet

Storage, in percent

Lake area, in percent

Forest, in percent

Soils index, in inches

Latitude of gage, in decimal degrees

Longitude of gage, in decimal degrees

Precipitation, in inches

Precipitation intensity for 2-year recurrence interval, in inches

2.45

3.30

55

5.2

42.0800

42.1086

42.0700

42.0828

42.0220

72.2480

72.1975

72.1242

72.0700

72.0575

71.9560

45

46

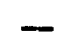

46

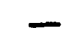

46

Snowfall, in inches

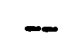

55

14
14
15
13.2

29.0

800

3.3

2.0

4.74

January minimum temperature, in degrees Fahrenheit 
Basin

characteristics

Station name and site number

$\begin{array}{ccccc} & \text { French River } & & \\ \text { below Hodges } & & \text { French } \\ \text { Tufts Branch } & \text { Village Dam, } & \text { Little River } & \text { Browns Brook } & \text { River at } \\ \text { at Dudley, } & \text { at Hodges } & \text { near Oxford, } & \text { near Webster, } & \text { Webster, } \\ \text { Mass. } & \text { Village, Mass. } & \text { Mass. } & \text { Mass. } & \text { Mass. }\end{array}$

(27)

(29)

(32)

Area, in square miles

1.10

31.2

26.0

0.49

84.0

Slope, in feet per

mile

169

-

56.8

182

Length, in miles

1.1

$-$

9.6

.99

Elevation, in feet

690

$-\quad 744$

780

Storage, in percent

1.7

-

$-$

2.19

Lake area, in percent

.0

-

3.94

.15

Forest, in percent

55

$-$

82

94

Soils index, in inches

4.6

$-$

4.6

5.2

Latitude of gage, in decimal degrees

42.0531

42.1183

42.1158

42.0567

42.0508

Longitude of gage, in decimal degrees

71.9394

71.8817

71.8906

71.8308

71.8856

Precipitation, in inches

42

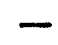

43

42

Precipitation intensity for 2-year recurrence interval, in inches

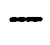

2.4

3.50

Snowfall, in inches

50

$-\quad 55$

50

January minimum

temperature, in

degrees Fahrenheit

15

$\begin{array}{ll}- & 7\end{array}$

16

${ }^{1}$ From Thomas, 1972. 
Table 4.--Streamflow characteristics, in cubic feet

per second, at selected stream-gaging stations

Annual and monthly flow characteristics:

QA is the mean annual discharge

SDQA is the standard deviation of mean annual discharge

$Q M$ is the mean discharge for $M$ calendar month, $M=1$ for January where the top line is

the maximum mean; the middle line is the mean; the bottom line is the minimum mean.

$\mathrm{SDQM}$ is the standard deviation of mean discharge for $\mathrm{M}$ calendar month

Low-flow characteristics:

$7 \mathrm{Q} 2$ is the annual minimum 7-day mean discharge for 2-year recurrence interval

$7 \mathrm{Q} 10$ is the annual minimum 7-day mean discharge for 10-year recurrence interval

Flow-duration characteristics:

DPT is the daily discharge, exceeded PT percent of the time, from the flow-duration curve

Years of record:

YRSDAY is the number of years of daily flow record for this analysis

YRSLOW is the number of years of low-flow record for this analysis

Flow

Station name and site number

Quinebaug Quinebaug

River below River below

Brimfield Westville

Dam, at Dam, near

Fiskdale, Southbridge, Mass. Mass.

(13) (16)
Quinebaug French River Little Browns French
River at below Hodges River Brook River
Quinebaug, Village Dam, near near at

Conn. at Hodges Oxford, Webster, Webster, Village, Mass. Mass. Mass. Mass.

(22)

(27)

(29)

(32)

(36)

ANNUAL

QA

136

168

260

54.6

48.2

1.11

151

SDQA

22.6

49.6

73.9

18.2

13.9

.28

45.2

MONTHLY

Q10

241

123

53.4

SDQ10

68.4

Q11

$$
226
$$

27.3

SDQ11

72.4

312

185

46.6

98.5

135
351

109

17.1

89.9

330

117

24.4

86.7

488

200

47.6
495

160

29.2

136

503

199

40.4

141

738

319

81.4
102

33.8

7.36

29.7

126

47.8

7.04

36.1

161

63.9

9.17

202
42.4
80.2

26.1

1.97

20.1

96.0

37.9

3.90

28.5

124

52.9

11.5

34.4

.92
228

84.0

26.5

61.1

322

119

24.0

85.0

.73

442

165

33.9 
Table 4.--Streamflow characteristics, in cubic feet per second, at selected stream-gaging stations (Continued)

Flow

Station name and site number

Quinebaug Quinebaug

River below River below

Brimfield Westville

Quinebaug

River at

French River Little

Browns

French

Dam, at Dam, near

Quinebaug,

below Hodges River

Brook

River

Fiskdale, Southbridge, Mass.

Conn.

(13)

Mass.

(22)

Village Dam, near near at

at Hodges Oxford, Webster, Webster, Village, Mass. Mass.

Mass.

Mass.

(27)

(29)

(32)

(36)

MONTHLY (Continued)

\begin{tabular}{|c|c|c|c|c|c|c|c|}
\hline Q1 & $\begin{array}{c}371 \\
217 \\
40.4\end{array}$ & $\begin{array}{r}517 \\
216 \\
47.9\end{array}$ & $\begin{array}{r}1028 \\
351 \\
79\end{array}$ & $\begin{array}{c}157 \\
68.4 \\
8.90\end{array}$ & $\begin{array}{r}154 \\
58.9 \\
14.4\end{array}$ & $\begin{array}{r}2.94 \\
1.37 \\
.45\end{array}$ & $\begin{array}{c}544 \\
189 \\
39.9\end{array}$ \\
\hline SDQ1 & 103 & 141 & 252 & 48.6 & 39.3 & .78 & 133 \\
\hline Q2 & $\begin{array}{c}308 \\
176 \\
46.2\end{array}$ & $\begin{array}{l}548 \\
222 \\
62.8\end{array}$ & $\begin{array}{l}845 \\
334 \\
83.0\end{array}$ & $\begin{array}{l}171 \\
71.2 \\
10.0\end{array}$ & $\begin{array}{r}143 \\
62.5 \\
13.7\end{array}$ & $\begin{array}{r}3.24 \\
1.47 \\
.52\end{array}$ & $\begin{array}{r}474 \\
198 \\
36.7\end{array}$ \\
\hline SDQ2 & 96.3 & 140 & 200 & 48.2 & 35.8 & .64 & 120 \\
\hline Q3 & $\begin{array}{l}361 \\
255 \\
202\end{array}$ & $\begin{array}{l}615 \\
342 \\
201\end{array}$ & $\begin{array}{r}1086 \\
552 \\
317\end{array}$ & $\begin{array}{r}259 \\
117 \\
52.9\end{array}$ & $\begin{array}{r}195 \\
103 \\
55.3\end{array}$ & $\begin{array}{l}5.03 \\
2.51 \\
1.25\end{array}$ & $\begin{array}{l}651 \\
316 \\
164\end{array}$ \\
\hline SDQ3 & 66.5 & 106 & 195 & 50.8 & 34.4 & 1.12 & 115 \\
\hline Q4 & $\begin{array}{l}252 \\
218 \\
151\end{array}$ & $\begin{array}{l}489 \\
329 \\
126\end{array}$ & $\begin{array}{l}736 \\
493 \\
186\end{array}$ & $\begin{array}{c}167 \\
106 \\
37.6\end{array}$ & $\begin{array}{c}151 \\
106 \\
33.5\end{array}$ & $\begin{array}{r}6.44 \\
2.08 \\
.83\end{array}$ & $\begin{array}{l}446 \\
300 \\
99.6\end{array}$ \\
\hline SDQ4 & 39.7 & 99.2 & 150 & 33.3 & 30.3 & 1.40 & 89.0 \\
\hline Q5 & $\begin{array}{c}180 \\
141 \\
97.4\end{array}$ & $\begin{array}{c}349 \\
201 \\
83.1\end{array}$ & $\begin{array}{l}519 \\
301 \\
135\end{array}$ & $\begin{array}{l}120 \\
63 \\
24.5\end{array}$ & $\begin{array}{r}112 \\
56.8 \\
25.7\end{array}$ & $\begin{array}{r}2.75 \\
1.46 \\
.71\end{array}$ & $\begin{array}{l}381 \\
182 \\
72.3\end{array}$ \\
\hline SDQ5 & 29.1 & 67.7 & 109 & 26.9 & 22.0 & .58 & 75.4 \\
\hline Q6 & $\begin{array}{l}95.4 \\
64.2 \\
43.8\end{array}$ & $\begin{array}{c}391 \\
122 \\
33.7\end{array}$ & $\begin{array}{r}543 \\
176 \\
46\end{array}$ & $\begin{array}{r}145 \\
34.8 \\
9.88\end{array}$ & $\begin{array}{r}102 \\
32.0 \\
9.19\end{array}$ & $\begin{array}{r}2.52 \\
.85 \\
.27\end{array}$ & $\begin{array}{l}373 \\
109 \\
46.8\end{array}$ \\
\hline SDQ6 & 16.9 & 94.9 & 138 & 34.2 & 23.2 & .64 & 80.2 \\
\hline Q7 & $\begin{array}{l}85.5 \\
40.3 \\
23.9\end{array}$ & $\begin{array}{c}150 \\
58.1 \\
12.8\end{array}$ & $\begin{array}{r}211 \\
85.2 \\
21.7\end{array}$ & $\begin{array}{c}60.7 \\
17.6 \\
7.33\end{array}$ & $\begin{array}{c}67.3 \\
16.2 \\
2.62\end{array}$ & $\begin{array}{l}.93 \\
.30 \\
.06\end{array}$ & $\begin{array}{r}149 \\
55.8 \\
23.8\end{array}$ \\
\hline SDQ7 & 19.3 & 38.3 & 59.8 & 14.8 & 17.2 & .29 & 39.9 \\
\hline
\end{tabular}


Table 4.--Streamflow characteristics, in cubic feet per second, at selected stream-gaging stations (Continued)

Flow

\section{Station name and site number}

Quinebaug Quinebaug

River below River below

Brimfield Westville

Dam, at Dam, near

Fiskdale, Southbridge, Mass.

(13)

Mass.

(16)

Quinebaug

River at

Quinebaug
Conn.

(22)
French River below Hodges Village Dam, at Hodges Village, Mass. Mass. (27)
Little River near (29)
Browns French Brook River near at Webster, Webster, Mass. (32)
Mass.

(36)

MONTHLY (Continued)

Q8

97.6
47.0
9.3

SDQ8

31.0

Q9

122
55.5
14.6

SDQ9

39.1
139

50.1

16.0

37.1

180

56.5

16.5

46.6
259

70.2

18.1

62.2

206

79.1

22.9

59.0

24.8

13.7

17.9

25.6

33.0

67.0

82.5

175

352

609

\section{5}

14.0

6.55

8.17

48.1

18.8

2.90

12.7

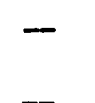

3.8

5.9

7.3

13.0

15.6

34.2

71.8

128

\section{4}

11.8

1.88

13.0

49.2

14.7

1.65

11.6

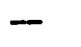

-

1.6

2.6

12.3

15.2

31.2

64.2

117

19

22

15

14
.00

7.6

.01

21.1

26.7

43.9

183

47.9

18.3

37.5

97.2

50.1

20.5

22.7

20.9

14.8

.04

.17

51.9

.26

.76

101

$1.6 \quad 200$

2.6

345

YEARS

\begin{tabular}{lrrrrrrr} 
YRSDAY & 8 & 18 & 18 & 19 & 22 & 15 & 20 \\
YRSLOW & - & - & 17 & - & - & 14 & 20 \\
\hline
\end{tabular}


Table 5.--Summary of 7-day low-flow characteristics, drainage area, and period of record for low-flow partial-record stations

\begin{tabular}{|c|c|c|c|c|c|c|}
\hline \multirow[t]{2}{*}{$\begin{array}{c}\text { Number } \\
\text { in } \\
\text { figure } \\
2\end{array}$} & \multirow[t]{2}{*}{$\begin{array}{l}\text { Station } \\
\text { number }\end{array}$} & \multirow[t]{2}{*}{ Station name } & \multirow[t]{2}{*}{ Location } & \multirow[t]{2}{*}{$\begin{array}{l}\text { Period } \\
\text { of } \\
\text { record }\end{array}$} & \multirow[t]{2}{*}{$\begin{array}{l}\text { Drainage } \\
\text { area, } \\
\text { in } \\
\text { square } \\
\text { miles }\end{array}$} & $\begin{array}{c}\text { Estimated } \\
\text { annual minimum } \\
7 \text {-day mean } \\
\text { low flow, in } \\
\text { cubic feet per } \\
\text { second, at } \\
\text { indicated } \\
\text { recurrence } \\
\text { interval } \\
\end{array}$ \\
\hline & & & & & & 2-year 10-year \\
\hline
\end{tabular}

MIDDLE RIVER BASIN

\begin{tabular}{|c|c|c|c|c|c|c|}
\hline 1 & 01119100 & $\begin{array}{l}\text { Sawmill Brook near } \\
\text { South Monson, } \\
\text { Mass. }\end{array}$ & $\begin{array}{l}\text { Stafford Hollow } \\
\text { Road }\end{array}$ & $1980-82$ & 1.49 & 0.2 \\
\hline , & 01119150 & $\begin{array}{l}\text { Middle River at } \\
\text { Ellithorpe, Conn. }\end{array}$ & State Route 32 & $1962-64$ & ${ }^{1} 6.46$ & - \\
\hline & 01119255 & $\begin{array}{l}\text { Delphi Brook near } \\
\text { Staffordville, } \\
\text { Conn. }\end{array}$ & State Route 19 & $1962-75$ & ${ }^{1} 2.59$ & - \\
\hline
\end{tabular}

\section{QUINEBAUG RIVER BASIN}

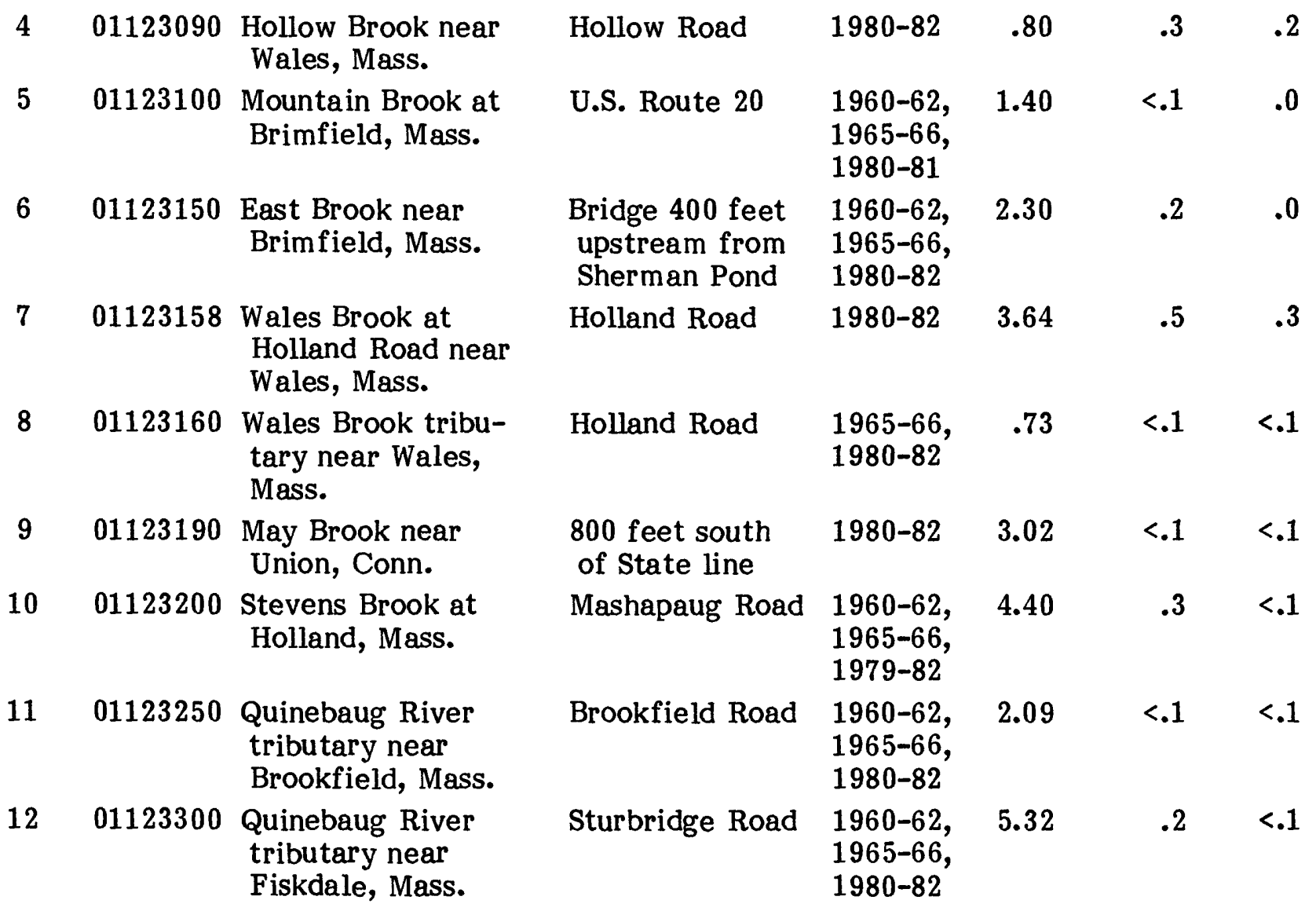


Table 5.--Summary of 7-day low-flow characteristics, drainage area, and period of record for low-flow partial-record stations (Continued)

\begin{tabular}{|c|c|c|c|c|c|c|}
\hline $\begin{array}{c}\text { Number } \\
\text { in } \\
\text { figure } \\
2\end{array}$ & $\begin{array}{l}\text { Station } \\
\text { number }\end{array}$ & Station name & Location & $\begin{array}{l}\text { Period } \\
\text { of } \\
\text { record }\end{array}$ & $\begin{array}{l}\text { Drainage } \\
\text { area, } \\
\text { in } \\
\text { square } \\
\text { miles }\end{array}$ & $\begin{array}{l}\text { Estimated } \\
\text { annual minimum } \\
\text { 7-day mean } \\
\text { low flow, in } \\
\text { cubic feet per } \\
\text { second, at } \\
\text { indicated } \\
\text { recurrence } \\
\text { interval }\end{array}$ \\
\hline & & & & & & $\overline{2 \text {-year } 10 \text {-year }}$ \\
\hline
\end{tabular}

\section{QUINEBAUG RIVER BASIN (Continued)}

1401123450 Hamant Brook near Sturbridge, Mass.

17

01123695 MeKinstry Brook near Charlton City, Mass.

1801123700 McKinstry Brook at Southbridge, Mass.

1901123800 Lebanon Brook near Southbridge, Mass.

$20 \quad 01123810$ Quinebaug River tributary no. 2 at Sandersdale, Mass.

2401124100 Tufts Branch near Dudley, Mass.
800 feet up- $1960-62$ stream from 1965-66 unnamed pond

Hill Road

1980-82

3.60

0.0

0.0

Plimpton Street

1960-62, 1965-66, 1980-81

State Route 169

$1960-62$, 1965-66, 1980-82

Road to treat- $\quad 1980-82$ ment plant

7.69

$.1<.1$

9.66

$.4 \quad .2$

State Route 197

1960-62, 1965-66, 1980-82

FRENCH RIVER BASIN

2501124250 Town Meadow Brook at Leicester, Mass.

$26 \quad 01124285$ French River at Oxford, Mass.

2801124390 Little River at Richardson Corners, Mass.

$30 \quad 01124505$ French River at Oxford, Mass.

$31 \quad 01124515$ French River trib utary at West Oxford, Mass.
Sargent Pond outlet

Cominsville Road

U.S. Route 20

Dudley Road

Nelson Street

$1980-82$

State Route 16

1937

1980-82

1937

1963-82
$1980-82 \quad 20.0$

2.0

.6

8.58

$1.1 \quad .6$

58.1

8.56

$2.0 \quad 1.0$

.49

.0

.0 
Table 5.--Summary of 7-day low-flow characteristies, drainage area, and period of record for low-flow partial-record stations (Continued)

Number

in Station

figure number

Station name

Location

Period

Drainage

of record area, in square miles

Estimated annual minimum 7-day mean low flow, in cubic feet per second, at indicated recurrence interval 2-year 10-year

\section{FRENCH RIVER BASIN (Continued)}

3301124800 Sucker Brook near Webster, Mass.

$34 \quad 01124900$ Mill Brook at Webster, Mass.

3501124910 Mill Brook near Webster, Mass.

$37 \quad 01125010$ French River at Perryville, Mass.

3801125020 Long Branch Brook at Wilsonville, Conn.

\begin{tabular}{|c|c|}
\hline Mine Brook Road & $\begin{array}{l}1960-62, \\
1965-66, \\
1979-82\end{array}$ \\
\hline $\begin{array}{l}\text { Lake Chaubuna- } \\
\text { gungamaug } \\
\text { outlet }\end{array}$ & $1936-37$ \\
\hline
\end{tabular}

Bigelow Road

1980-81

10.7

$1.9 \quad 1.2$

Perryville Road 1913, 93.2

1937

Labby Road

1980 ,

1982
$0.1<0.1$

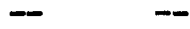

\section{QUINEBAUG RIVER BASIN (Continued)}

39

01125780 Rocky Brook at East Thompson, Conn.

- 01125300 English Neighborhood Brook at Nor th Woodstock, Conn.

- 01125400 Muddy Brook at East Main Street Woodstock, Conn.
East Thompson 1980-82

Road

State Route $93 \quad 1960-81 \quad{ }^{1} 4.66 \quad-\quad * .07$

$1961-81^{1} 13.1$

*Calculated from equation developed by Cervione and others, 1982.

${ }^{1}$ From Thomas, 1972.

${ }^{2}$ Recording gage, see table 2. 


\section{SELECTED REFERENCES}

Benson, M. A., 1962, Factors influencing the occurrence of floods in a humid region of diverse terrain: U.S. Geological Survey Water-Supply Paper 1580-B, 64 p.

Brackley, R. A. and Wandle, S. W., Jr., 1982, Drainage divides, Massachusetts-Nashua and Concord River basins: U.S. Geological Survey Open-File Report 82-924, 22 maps.

Cervione, Jr., M. A., Melvin, R. L. and Cyr, K. A., 1982, A method for estimating the 7-day, 10-year low flow of streams in Connecticut: Connecticut Water Resources Bulletin No. $34,17 \mathrm{p}$.

Halliwell, D. B., Kimball, W. A., and Screpetis, A. J., 1982, Massachusetts stream classification program, part I, Inventory of rivers and streams: Massachusetts Department of Environmental Quality Engineering and Department of Fisheries, Wildlife, and Recreational Vehicles, 126 p., appendix consisting of 3 pages.

Higgins, G. R., 1967, Yield of streams in Massachusetts: Amherst, Massachusetts, University of Massachusetts, Water Resources Research Center Publication 5, 175 p.

Hutchison, N. E., compiler, 1975, WATSTORE-National water data storage and retrieval system of U.S. Geological Survey--User's guide: U.S. Geological Survey Open-File Report 75-426, 791 p. (revised).

Johnson, C. G., 1970, A proposed streamflow data program for central New England: U.S. Geological Survey open-file report, 38 p., 1 appendix consisting of 11 pages.

Johnson, C. G., and Tasker, G. D., 1974, Progress report on flood magnitude and frequency of Massachusetts streams: U.S. Geological Survey Open-File Report 74-131, 41 p.

Knox, C. E., and Nordenson, T. J., 1955, Average annual runoff and precipitation in the New England-New York area: U.S. Geological Survey Hydrologic Investigations Atlas 7, 6 p.

Knox, C. E., and Soule, R. M., 1949, Hydrology of Massachusetts, part 1, Summary of streamflow and precipitation records: U.S. Geological Survey Water-Supply Paper 1105, 240 p.

Krejmas, B. E., 1982, Drainage divides, Massachusetts-Blackstone and Thames River basins: U.S. Geological Survey Open-File Report 82-631, 12 maps.

Krejmas, B. E., and Wandle, S. W., Jr., 1982, Drainage divides, Massachusetts-Connecticut River lowlands and Chicopee River basin: U.S. Geological Survey Open-File Report 82-633, 18 maps.

Langbein, W. B. and Iseri, K. T., 1960, General introduction and hydrologic definitions, in Manual of hydrology, part 1, GeneraI surface-water techniques: U.S. Geological Survey WaterSupply Paper 1541-A, p. 1-29.

Langbein, W. B., and others, 1947, Topographic characteristics of drainage basins: U.S. Geological Survey Water-Supply Paper 968-C, p. 125-157.

Lautzenheiser, R. E., 1969, Snowfall, snowfall frequencies, and snow cover data for New England: Environmental Sciences Services Administration Technical Memorandum EDSTM 12, $15 \mathrm{p}$.

Male, J. W., and Ogawa, H., 1982, Low flows of Massachusetts streams: Amherst, Massachusetts, University of Massachusetts, Water Resources Research Center Publication 125, $152 \mathrm{p}$. 
Meeks, W. C., 1977, Daily values statistics (program A969), in Hutchison, N. E., compiler, 1975, WATSTORE--National water data storage and retrieval system of the U.S. Geological Survey user's guide: U.S. Geological Survey Open-File Report 75-426 (revised), chap. IV, section G.

Price, W. E., Jr., and Meeks, W. C., 1977, Daily values monthly and annual statistics (program W4422), in Hutchison, N. E., compiler, 1975, WATSTORE-National water data storage and retrieval system of the U.S. Geological Survey user's guide: U.S. Geological Survey Open-File Report 75-426 (revised), chap. IV, section F.

Riggs, H. C., 1971, Discussion of probability distribution of annual droughts by Eratakulan S. Joseph: American Society of Civil Engineers Proceedings, v. 97, no. IR3, p. 540-541.

1972, Low-flow investigations: U.S. Geological Survey Techniques of Water-Resources Investigations, book 4, chap. B1, 18 p.

Thomas, M. P., 1972, Gazetteer of natural drainage areas of streams and water bodies within the State of Connecticut: Connecticut Department of Environmental Protection Bulletin No.1, 89 p.

Thomas, D. M., and Benson, M. A., 1970, Generalization of streamflow characteristics from drainage-basin characteristics: U.S. Geological Survey Water-Supply Paper 1975, 55 p.

U.S. Department of Agriculture, 1972, Soil Conservation Service National Engineering Handbook, section 4, Hydrology: U.S. Department of Agriculture, Soil Conservation Service.

U.S. Federal Inter-Agency River Basin Committee, Subcommittee on Hydrology, 1951, Interagency coordination of drainage area data, notes on hydrologic activities: Water Resources Council, Subcommittee on Hydrology Bulletin no. 4, 48 p.

U.S. Geological Survey, 1977, National handbook of recommended methods for water-data acquisition: U.S. Geological Survey, chap. 7, 38 p.

1980, Water resources data for Massachusetts and Rhode Island, water year 1979: U.S. Geological Survey Water-Data Report MA-RI-79-1, 349 p.

U.S. Weather Bureau, 1959a, Climates of the states, Massachusetts: U.S. Weather Bureau, Climatography of the United States, Paper No. 60-19, 20 p.

$1959 \mathrm{~b}$, Rainfall intensity-frequency regime, northeastern United States: U.S. Weather Bureau Technical Paper no. 29, 35 p.

Wandle, S. W., Jr., 1981, Drainage divides, Massachusetts--Hudson River basin: U.S. Geological Survey Open-File Report 81-1189, 5 maps.

1982, Estimating peak discharges of small, rural streams in Massachusetts: U.S. Geological Survey Open-File Report 80-676, 33 p.

1983, Low-flow frequency and flow-duration analysis of natural-flow streams in Massachusetts: Boston Society of Civil Engineers Section, American Society of Civil Engineers Journal, v. 69 , no. 1 , p. 87-110.

1984a, Gazetteer of hydrologic characteristics of streams in Massachusetts-coastal river basins of the North Shore and Massachusetts Bay: U.S. Geological Survey Water-Resources Investigations Report 84-4281. 
Wandle, S. W., Jr., 1984b, Gazetteer of hydrologic characteristics of streams in MassachusettsConnecticut River basin: U.S. Geological Survey Water-Resources Investigations Report 84-4282.

$1984 \mathrm{c}$, Gazet teer of hydrologic characteristics of streams in Massachusetts-Hudson River basin: U.S. Geological Survey Water-Resources Investigations Report 83-4250.

Wandle, S. W., Jr., and Fontaine, R. A., 1984, Gazetteer of hydrologic characteristics of streams in Massachusetts-Merrimack River basin: U.S. Geological Survey Water-Resources Investigations Report 84-4284.

Wandle, S. W., Jr., and Keezer, G. R., 1984, Gazetteer of hydrologic characteristics of streams in Massachusetts-Taunton and Ten Mile River basins and coastal river basins of Mount Hope Bay, Narragansett Bay, and Rhode Island Sound: U.S. Geological Survey WaterResources Investigations Report 84-4283.

Wandle, S. W., Jr., and Lippert, R. G., 1984, Gazetteer of hydrologic characteristics of streams in Massachusetts--Housatonic River basin: U.S. Geological Survey Water-Resources Investigations Report 84-4285.

Wandle, S. W., Jr., and Morgan, M. A., 1984, Gazet teer of hydrologic characteristics of streams in Massachusetts-coastal river basins of the South Shore and Buzzards Bay: U.S. Geological Survey Water-Resources Investigations Report 84-4288.

Wandle, S. W., Jr., and Phipps, A. F., 1984, Gazetteer of hydrologic characteristics of streams in Massachusetts-Blackstone River basin: U.S. Geological Survey Water-Resources Investigations Report 84-4286. 